\title{
Evaluation of the trading development in the Iberian Energy Derivatives Market
}

\author{
Álvaro Capitán Herráiz*, Carlos Rodríguez Monroy \\ Department of Business Administration, Technical University of Madrid (UPM), Madrid, Spain
}

\section{H I G H L I G H T S}

- The continuous traded volumes in the lberian power futures market grow steadily.

- Those volumes are correlated to OTC volumes and the enrolment of key players.

- Most liquid contracts show the smallest hedging ratio.

- Regulation fixing the coal fired generation price affects spot and forward prices.

- The overall efficiency can grow via market monitoring reports and oTC data access.

\begin{abstract}
A B S T R A C T
The efficiency of the Iberian Energy Derivatives Market in its first five and a half years is assessed in terms of volume, open interest and price. The continuous market shows steady liquidity growth. Its volume is strongly correlated to that of the Over The Counter (OTC) market, the amount of market makers, the enrolment of financial agents and generation companies belonging to the integrated group of last resort suppliers, and the OTC cleared volume in its clearing house. The hedging efficiency. measured through the ratio between the final open interest and the cleared volume, shows the lowest values for the Spanish base load futures as they are the most liquid contracts. The ex-post forward risk premium has diminished due to the learning curve and the effect of the fixed price retributing the indigenous coal fired generation. This market is quite less developed than the European leaders headquartered in Norway and Germany. Enrolment of more traders, mainly international energy companies, financial agents, energy intensive industries and renewable generation companies is desired. Market monitoring reports by the market operator providing post-trade transparency, OTC data access by the energy regulator, and assessment of the regulatory risk can contribute to efficiency gains.
\end{abstract}

\section{Introduction}

This research analyses the efficiency of the Iberian Energy Derivatives Market, the power futures market managed by OMIP ("Iberian Market Operator, Portuguese Pool"), by means of the evolution of three key indicators: (i) the traded volumes (reflecting the liquidity development); (ii) the open interest (reflecting the trading behaviour, as it shows the net positions of OMIP trading members, i.e. the amount of futures contracts that may be used for hedging against the volatility and uncertainty of the underlying spot price); and (iii) the ex-post forward risk premium

\footnotetext{
'Corresponding author. Tel: + 34 656635983; fax: + 34913363005

E-mail addresses: alvarocapitan@hotmail.com (Á. Capitán Herráiz), crmonroy@etsii.upm.es (C. Rodríguez Monroy).
}

(reflecting the price efficiency). This market started operating on July 3, 2006. The derivatives data set considers the first five and a half years (i.e. traded volumes until December 31, 2011).

The evolution of the Spanish electricity market in the last months has been influenced by the introduction of new regulation. Section 2 provides a snapshot of the Spanish electricity policy influencing the wholesale power market. This section is focused on the main measures affecting the performance of the electricity forward market. The evolution of the rraded volumes in the power futures market compared to the rest of existing forward contracting mechanisms is presented in Section 3. The analysis of the open interest and its relation to the traded volumes is shown in Section 4. The evolution of the ex-post forward risk premium is tracked in Section 5. Section 6 provides policy considerations derived from the analyses performed in the previous sections with the aim of contributing to higher efficiency 


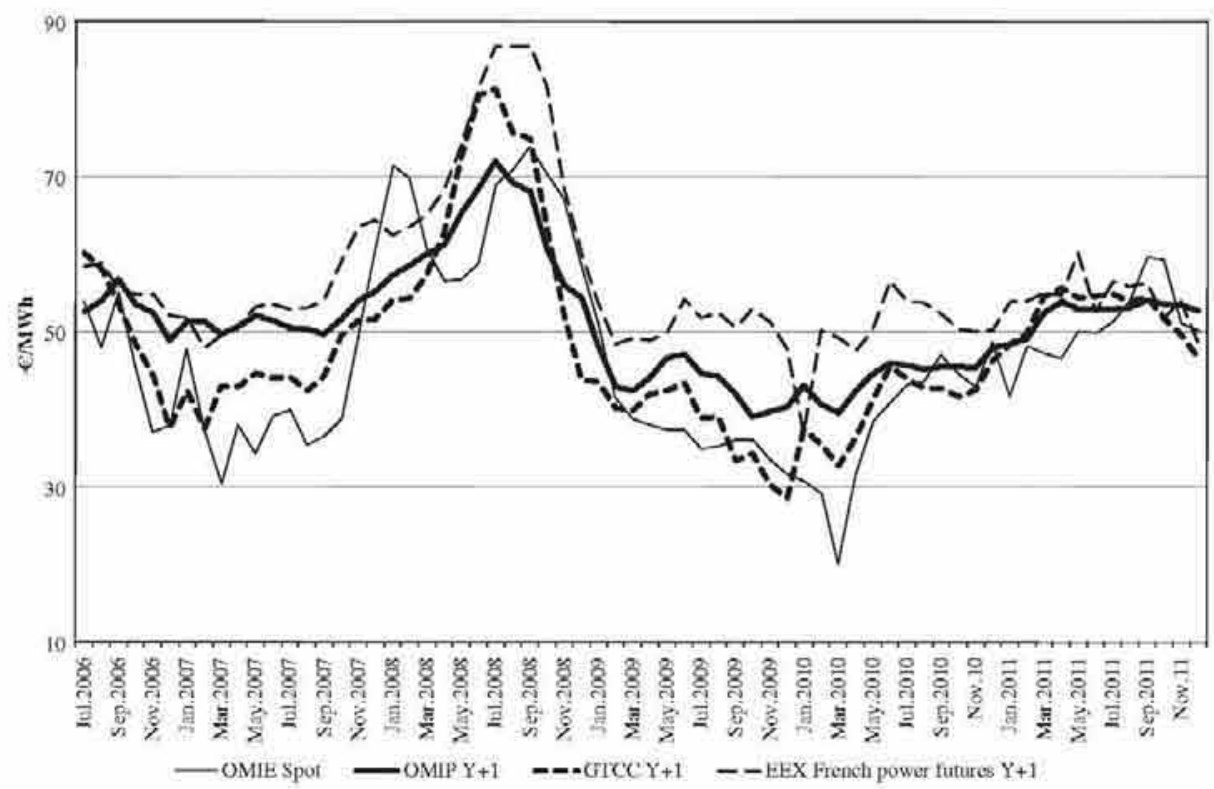

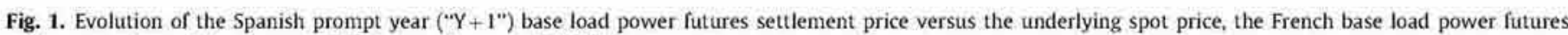
settlement price and the forward GTCC generation costs ( $\epsilon / \mathrm{MWh})$.

Sources: OMIP-OMIClear, OMIE. EEX. Platts and ICF., adapted by authors.

levels. Section 7 summarises all the findings, suggests further lines of research and concludes.

\section{The current electricity policy context}

\subsection{The subsidised coal fired generation with indigenous coal}

The Royal Decree 134/2010, of 12 February, 2010, compelling the Spanish coal power plants to burn indigenous coal at a regulated price for the sake of security of supply, in force on February 26, 2011. fixes the generation costs of 10 coal power plants. For year 2011, the variable cost of the coal plant with biggest production is around $53 \mathrm{E} / \mathrm{MWh}$, being the weighted average price of the 10 plants, according to their maximum allowed volumes, equal to $55.30 \mathrm{E} / \mathrm{MWh}$. As a consequence, this policy measure sets a price threshold in the merit order curve of the spot market (MITyC, 2010, 2011a). As indicated in CNE (2012a), this mechanism produced in the second quarter of year 2011 a smoother merit order curve in the day ahead market. It reduced the peak price and increased the off-peak price, disappearing the price signal needed for the efficient consumption. As the day ahead market became more expensive, the suppliers not belonging to the incumbents purchased in year 2011 the major part of their energy in the subsequent intra-day markets. These markets, composed of 6 sequential auctions, resulted in average in year $20111.7 \mathrm{E} / \mathrm{MWh}$ cheaper than the day-ahead market. From August 2011, the prices in the day ahead market increased due to more expensive offers of Gas Turbine Combined Cycles (GICC). This was caused by higher lberian gas prices, motivated by a larger demand of liquefied natural gas by Japan, in the aftermath of Fukushima nuclear accident. Therefore, in the second half of year 2011, the Spanish spot price was more expensive with the exception of November-than in the main European power markets (Nord Pool (Nordic countries) and European Power Exchange "EPEX" (France, Germany, Austria and Switzerland)).

The following subsection analyses the main drivers of the Spanish electricity forward price formation and the impact of the Royal Decree 134/2010.
2.1.1. The impact of the recognised price of the indigenous coal fired generation in the Spanish forward price formation

The GICC generation accounts in Spain in 2009 for $24.2 \%$ of the installed capacity and for $29 \%$ of the electricity gross generation, being the main technology in the generation mix (Moreno and Martinez-Val, 2011). However, due to the effect of the recognised price for the coal fired generation with indigenous coal, the GTCC production passed from 63 TWh in year 2010 to 50 TWh in year 2011 (the load factor, obtained as the ratio between the equivalent working hours and the total amount of hours in a year, diminished from $30 \%$ to $22 \%$ ) (CNE, 2012a). The Spanish electricity forward prices are influenced by the spot prices, the fuel prices especially the gas prices and the international electricity forward prices (Villaplana and Cartea, 2011). Fig. 1 shows the evolution of the Spanish prompt year base load futures contract, compared to the underlying spot price $\left(\mathrm{OMIE}^{1}\right.$ spot price), the French prompt year base load futures contract traded in the European Energy Exchange (EEX), and the forward estimation of the GTCC generation costs. Monthly average values are used for each energy price. The settlement price of the Spanish prompt year power futures stabilises around $53 \mathrm{E} / \mathrm{MWh}$ since March 2011 influenced by the entry in force of Royal Decree 134/2010.

Table 1 shows high correlation coefficients of the Spanish prompt year base load power futures price with the GTCC generation cost, the French prompt year base load power futures price, and the Spanish power spot price.

The clean spark spread is obtained as the difference between the Spanish power futures price and the forward GTCC generation cost taking into account the $\mathrm{CO}_{2}$ emission rates (e.g. Abadie and Chamorro, 2009). For the gas prices, Platts assessments of prompt year base load forward contract traded OTC ("Over The Counter", i.e. out of organised markets) in the Dutch virtual trading point (TTF, "Title Transfer Facility") are used. The Spanish gas market lacks of price transparency, as physical swaps for balancing purposes are arranged amongst participants without disclosing the price (Honoré, 2011; CNE, 2012b). Therefore a liquid reference in continental Europe has been taken instead. For the $\mathrm{CO}_{2}$

\footnotetext{
' OMIE stands for "Iberian Market Operator, Spanish Pool"
} 


\section{Table 1}

Correlation coefficients of the Spanish prompt year base load power futures settlement price with the underlying spot price, the French prompt year power futures and the forward GTCC Generation Costs.

Sources: OMIP-OMIClear, OMIF, EEX, Platts and ICE, adapted by authors.

Prompt year forward GTCC generation costs

French power prompt year futures price

Spanish power spot price

emissions, European Union Allowances (EUA) futures settlement prices in the Inter Continental Exchange (ICE) are considered. The GTCC generation cost is calculated as the sum of the gas forward price, divided by the thermal efficiency of the power plant, and the price of the $\mathrm{CO}_{2}$ allowance multiplied by the emission rate. As in Abadie and Chamorro (2009), a thermal efficiency of $55 \%$ and a emission rate of $0.37 \mathrm{tCO}_{2} / \mathrm{MWh}$ are employed. As shown in Fig. 1, in the majority of the months, the clean spark spreads are positive (generation profits). There are some periods with negative spreads (second and third quarters of 2008 and 2011).

The Spanish prompt year futures price tends to be smaller than the neighbouring French power futures price. There are only few months with Spanish futures prices bigger than French ones, being the price difference smaller than in the opposite case. During year 2011, the Spanish price exceeds more often the French price influenced by the price level bound to Royal Decree $134 / 2010$.

The Spanish prompt year futures price tends to be higher than the underlying spot price ("contango"). However, in year 2008, the spot price was often bigger than the futures price, especially in the second half of the year ("backwardation"). At that time, the futures prices were influenced by downward prognoses due to the global financial turmoil. During year 2011, the Spanish spot and futures prices present smaller differences influenced by the price level set by Royal Decree 134/2010.

\subsection{The moratorium to renewables}

The deployment of renewable energy sources in the last 20 years has been outstanding in Spain (Moreno and Martinez-Val, 2011). However, the Royal Decree-Law 1/2012 freezes temporarily the grant of new feed-in tariff contracts to contain the large tariff deficit, as a portion of this deficit is caused by large incentives to the renewable energy sources. For instance, the market premium to solar technologies in 2010 exceeded 2000 million $f$ (MINETUR, 2012a). This Royal Decree-Law could affect negatively about $4500 \mathrm{MW}$ and $550 \mathrm{MW}$ of wind and solar photovoltaic power projects respectively, as well as other special regime (renewables and cogeneration) projects (Energy Market Price, 2012). Nonetheless, a significant amount of renewable generation (ca. 11,000 MW) officially registered at the entry into force of the Royal Decree-Law can be installed, not being affected by the moratorium (Ordônez, 2012). García Breva (2012) warns about the regulatory risk damaging the development of Spanish renewable energy sources, due to continuous changes in the special regime regulation. After the entry into force of the key regulation (Royal Decree 661/2007, of 25 May, 2007, regulating the special regime production), a new Decree has been introduced every six months generating uncertainty to investors.

The effects of maintaining this moratorium should be analysed cautiosly by policy makers, due to the effect of the renewable energy sources in diminishing the $\mathrm{CO}_{2}$ emissions of the generation mix and the reduction of spot prices. Gelabert et al. (2011) study ex-post the effects of special regime generation on Spanish wholesale electricity prices, with data for years 2005-2009. They find that a marginal increase of $1 \mathrm{GWh}$ of special regime

generation is associated with a reduction of ca, $4 \%$ in wholesale power prices.

The special regime power plants profiting of a feed-in-tariff scheme can sell the electricity at a fixed price. Those installations affected by Royal Decree-Law 1/2012 may now be interested in hedging their production in the futures market or OTC.

\subsection{The extension of life cycle of power plants}

Whereas the GTCC and renewable sources in Spain are quite modern, as they have mainly been installed in the last 20 years, the nuclear plants - built in the nuclear boom of the 70 s and $80 \mathrm{~s}$ - and the coal power plants are older. Continuous debate is created about the extension or closure of the ageing Spanish nuclear plants. No new nuclear power plants are envisaged. Such new investments are surrounded of several uncertainties (Linares and Conchado, 2010). The effects on power prices due to the extension of life cycle of power plants are different depending on the generation technology. In the case of nuclear power plants, the extension produces smaller spot and forward prices, due to the base load nature of this technology. On the other hand, Sensfuß et al. (2008) detect that the extension of life cycle of old thermal power plants (coal and fuel oil) creates upward price pressure in the wholesale power prices due to higher inefficiency of such aged plants.

\subsubsection{The effect of the German nuclear moratorium on power prices}

After the Fukushima nuclear disaster on March 11, 2011, the German government discussed the shutdown of nuclear power by 2022. This moratorium was officially announced on March 14 , 2011 , stopping 7 nuclear reactors ( $5.3 \mathrm{GW}$ ). On May 21, 2011, the German government decided to shut down progressively all the nuclear reactors by 2022 . The German power market joined the Trilateral Coupling in the Central West European Region-formed by the French, Belgian, and Dutch markets on November 9 , 2010. The market coupling algorithm provides a unique spot price in the region in the absence of congestion in the interconnection. Therefore their price spreads (both spot and futures) diminished with the introduction of the algorithm. However, the German moratorium has produced a smaller spot price convergence between the German and French prices (the French prices were $1.8 \mathrm{E} / \mathrm{MWh}$ cheaper in the first half of year 2011) and the inversion in the price level of the year futures (the German forward prices have become more expensive) (CRE, 2011).

\subsection{The mitigation of large cost deficits in the electricity sector}

\subsubsection{Policy recommendations by the National Regulatory Authority}

The Spanish national regulatory authority CNE (2012b) indicates the existence of a structural deficit in the Spanish electricity sector since a decade, as the recognised costs for regulated activities have been (and are) higher than the incomes from regulated prices paid by consumers. The deficit at March 6, 2012, reckons 21,812 million $€(23,312$ million $f$ including the established deficit for year 2012). In order to tackle this deficit, CNE (2012b) suggests short term (i.e. urgent) measures, as the cost review of regulated activities and the delay of planned investments, the utilities' cession of part of the generated debt to third parties, the pass through of the System Operator's retribution and the large consumers' interruption cost (they would be considered as energy costs rather than access costs), the charge of the capacity availability payments and generation investment incentives on the market participants instead of the consumers, the elimination of the financing of the insular costs by the mainland power system, the financing of feed-in tariff costs through the incomes of the $\mathrm{CO}_{2}$ auctions, and the temporary lamination of the 
premiums for the concentrating solar power plants already registered but still not working. As medium term measures, $\mathrm{CNE}$ (2012b) suggests to review the unit costs and the asset retribution basis (i.e. update of the incentive based regulation), the attribution to the $\mathrm{CNE}$-instead of the Ministry of Industry - for establishing the methodology of retribution of the regulated activities, and the introduction of renewable auctions.

\subsubsection{The first measures taken by the government}

The Royal Decree-Law 13/2012, of 30 March, diminishes the costs in the electricity and gas systems. It aims that the third party access rates are sufficient to cover the regulated costs, taking into account the foreseen ex-ante deficit for 2012. The following measures stated in this Royal Decree-Law may affect the performance of the electricity forward market: (i) The capacity payments ${ }^{2}$ are reduced 80 million $€$ (this can produce higher spot prices in the peak hours, increasing the forward risk premium embedded in the forward prices; in this sense, the risk premia increase when the generators' profits are less stable (Fabra, 2009)); (ii) the retribution to the interruption services by large consumers will be reduced 60 million $\epsilon$ (such consumers may now be incentivised to contract instead firm services, producing an upward pressure in the spot and forward prices; additionally, a bigger demand on firm services may produce a change in the energy tariff cost structure to reflect this need properly); (iii) the recognised payments to the coal fired generation with indigenous coal will be limited to 50 million $\epsilon$ (the reduction of recognised incomes to older coal plants may increase the spot and forward prices, in line with Sensfuß et al. (2008)) (MINETUR, 2012b, 2012c).

Regarding the neighbouring country, the Portuguese government also envisages immediate energy policy reforms. Those measures will also focus on strict control of the energy systems costs in a first phase, followed by their reduction in a second phase. For instance, the state costs related to the supervision of the electricity and gas concessions will have to be paid by the consumers through the end-user tariffs (Cabral, 2012).

\subsection{The introduction of household hourly tariffs}

As indicated by CNE (2012b) and MINETUR (2012b), a review of the cost components is needed to ensure that the Third Party Access rates cover the costs of the electricity sector. Additionally to this, changes in the domestic end-user tariffs are needed to take into account the benefits of smart grids and smart meters, helping to a massive demand response that increases the efficiency of the whole power system (Conchado and Linares, 2010). Moreno (2011) indicates that hourly rates and smart meters are widely used by large consumers since the liberalisation of the electricity sector in 2008 . Such a research detects the positive effect of liberalisation correcting inefficient trends of electricity demand in Spain. Time-of-use tariffs for household consumption would be adequate if such prices are not set by the government (e.g. for consumers with power exceeding $2 \mathrm{~kW}$ ) and they are liberalised. The gradual introduction of smart meters in 25 millions of households (i.e. power less than $15 \mathrm{~kW}$ ) in Spain, as envisaged by the Plan of meters substitution, has not become a reality yet. This plan should be completed by 2018 (MITyC, 2009b). Cabeza (2011) indicates that in 2014 half of those meters would be installed and the remote system would be working.

\footnotetext{
3 A regulated payment for the generation plants providing capacity. It includes 2 services: the long term investment incentive and the medium term generation availability. The CNE is currently assessing the introduction of a capacity market mechanism to streamiline this issue (CNE, 2012a, 2012b).
}

Regulatory developments establishing a national plan for active management of the power demand are needed to take full advantage of these devices. The major Spanish utilities have developed pilot projects of smart grids in cities where their distribution companies have installed smart meters. Joskow and Wolfram (2011) indicate that the introduction of time-varying electricity prices for households in the US is slow despite of decreasing device costs and improved functionality for meters and automated demand response technologies. They think that most utilities will begin offering alternative tariffs while leaving flat-rate pricing the default option.

The massive deployment of dynamic pricing of electricity can reduce the price spikes. The price differences between peak and off-peak periods would then fall. Therefore, average spot prices would decrease as well as the forward risk premium.

\section{Evolution of the trading efficiency}

The trading efficiency of the lberian energy derivatives market is analysed according to its main structural features. First, its volume development is compared with the rest of existing forward market mechanisms. Its concentration basic figures are compared with those of the generation and supply activities. The key trading drivers of OMIP continuous market are identified. Additionally. this futures market is compared with the main European benchmarks.

\subsection{Volume comparison between Iberian forward trading mechanisms}

The evolution of OMIP traded volumes has to be seen in conjunction with the dominant non-organised OTC market-in Spain, financial trading either done bilaterally or with the intermediation of brokers, being a portion of them cleared and settled through clearing houses and with the volumes matched in the regulated auctions for the Spanish last resort supplies ("CESUR" auctions ${ }^{3}$ ). Although the first CESUR auction was celebrated in June 2007, covering part of the regulated supplies by the distribution companies, the last resort supplies - managed by new companies, the so-called "last resort suppliers" belonging to the same vertical group of those distribution companies - substituted such regulated supplies since July 1,2009 , according to Royal Decree 485/2009 (MITyC, 2009a).

Fig. 2 shows the evolution of the cleared and settled volumes (in TWh) in OMIClear (OMIP clearing house), and the matched volumes in CESUR auctions. It additionally shows the cleared volumes in another clearing house (MEFF Power), which started operation on March 21, 2011, for the clearing and settlement of OTC power trades with Spanish underlying spot prices. MEFF stands in Spanish for "Spanish Financial Futures Market" (BME, 2011; MEFF, 2011).

There are two market modes in OMIP; the continuous market and auctions. Whereas the former is the main mode, the latter has performed a key role in the development of the liquidity in OMIP, as the Spanish distribution companies and the Portuguese last resort supplier were obliged to purchase energy in such auctions until July 2009 and July 2010 respectively (Capitán Herráiz and Rodríguez Monroy, 2009). Furthermore OMIClear permits the clearing and settlement of OTC volumes by OMIP trading members, either bilaterally or through one of the four registered brokers. In the period June 2007-December 2011, 17 CESUR auctions have been celebrated sourcing part of the last resort

\footnotetext{
3 "CESUR" stands in Spanish for "Energy Contracts for the Last Resort Supply"
} 


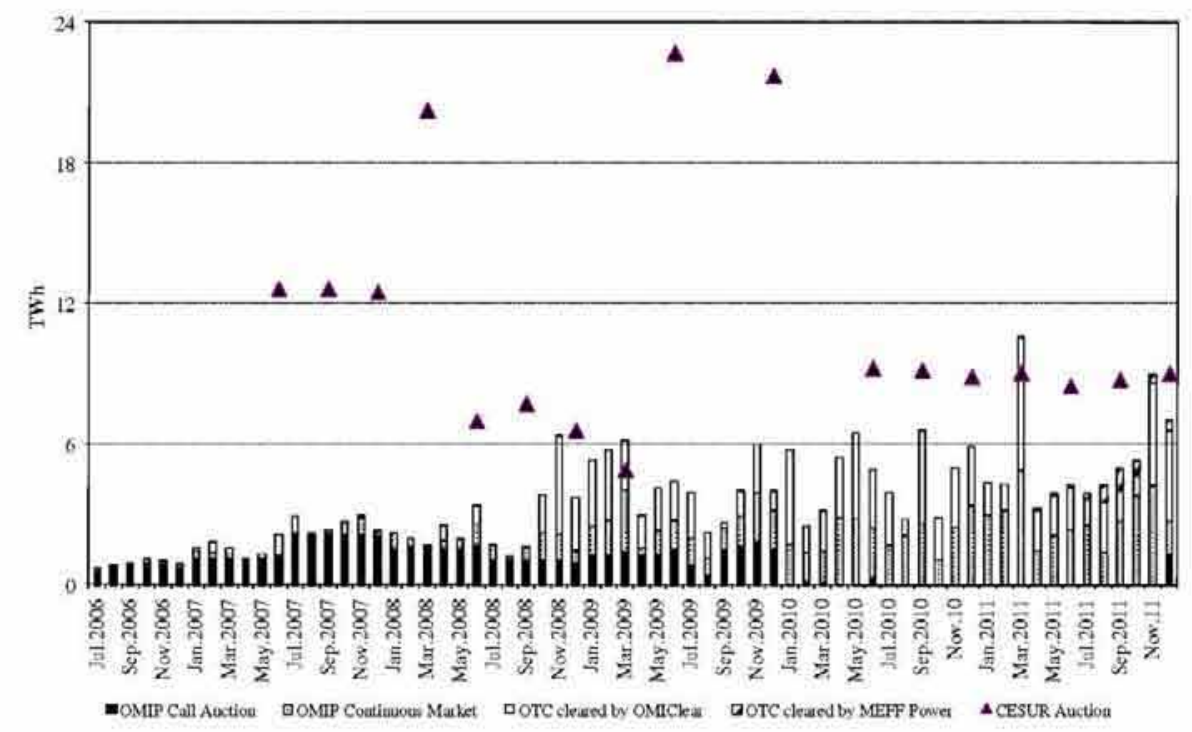

Fig. 2. Evolution of traded and cleared volumes in OMIP-OMIClear, traded volumes in CFSUR auctions, and cleared volumes in MEFF Power (TWh). Sources: OMIP-OMIClear (2011), CESUR (2011), MEFF (2011).

supplies. The last resort suppliers purchase the remaining part in the spot market. Prior to each CESUR auction, they have to communicate to the Ministry of Industry their load forecast. Since March 2011, they hedge the part of their forecast not covered by the CESUR auction at the same equilibrium price by means of a contract for differences mechanism regulated by Royal Decree $302 / 2011$. The counterparties are the special regime facilities selling their energy in the spot market (day ahead and intra-day auctions) and receiving a fixed price ("regulated rate"). As the equilibrium prices of the CESUR auctions are usually bigger than the underlying spot price, the rents obtained from this mechanism help to mitigate the part of the tariff deficit generated by the regulated rate recognised to such special regime facilities (CESUR, 2011; MITyC, 2011b).

OMIP traded volumes in the first two years i.e. from July 2006 to June 2008 - were led by compulsory auctions. Since that moment until the end of 2009 the continuous volumes reached a similar size to the auction ones. Afterwards, the continuous market volumes kept growing. During 2010, the scarce auction volumes were generated by compulsory auctions of peak futures for the Portuguese last resort supplier. OMIP peak futures are still very illiquid. The month with record of continuous volumes was March 2011 (4.86 TWh). The OTC cleared volumes also reached a record in that month (5.68 TWh) and maintained a growing trend, influenced by the strong OTC trading development (OMIPOMiClear, 2011).

Since March 21, 2011, OrC power trades with Spanish underlying spot prices can also be cleared and settled by MEFF Power. Although the number of enroled members in MEFF Power is growing fast ( 25 at the end of December 2011, of which 13 are also active in OMIP, which has 38 members at that date ${ }^{4}$ ) the registered volumes until the end of December 2011 are still small (3.8 TWh) compared to the OTC registered volumes in OMIClear in the same period (24.5 GWh) (MEFF, 2011; OMIP-OMIClear. 2011).

Table 2 shows the traded volumes in OMIP, in CESUR auctions and OTC, as well as the cleared and settled OTC volumes in the

\footnotetext{
${ }^{4}$ On the other hand. Alba Rios and Moreda Diaz (2010) indicate that the Spanish OTC market is composed of around 25 players (gas and power companies, financial entities, large consumers and commodity traders). The number of participants in the CESUR auctions is around 30 (CNE, 2011a).
}

2 clearing houses. Additionally, it shows the Spanish mainland demand at busbar. Values for year 2011, year 2010, and the whole period covered by this research (July 2006-December 2011) are provided. The traded volumes in OMIP (auction and continuous). CESUR auctions, and OTC grow in year 2011 compared to year 2010. Conversely, the OTC registered volumes in OMIClear and the demand diminish in year 2011. The CESUR volumes are only $7 \%$ bigger than OMIP continuous volumes in that year. The OTC market has experienced a steady growing trend, summing up in the whole period ca. 863 TWh. The first two years in which the OTC volumes are bigger than the demand (i.e. a "churn" ratio ${ }^{5}$ bigger than 1) are the years 2010 and 2011. The accumulated OTC volumes are 10.3 times bigger than OMIP continuous volumes and 4.5 times bigger than CESUR matched volumes. Only a minor part of the whole OTC volume is centrally cleared: $10.4 \%$ by OMIClear and $1.4 \%$ by MEFF Power (OMIP-OMIClear, 2011; MEFF, 2011; CESUR, 2011; Intermoney, 2012; REE, 2012).

\subsection{Competition in the power futures market}

According to the futures market operator, this market became less concentrated during year 2010 and the market share of the three biggest players accounted for $40 \%$ in the last months of 2010 (OMIP, 2011). This share compares well against the generation and supply concentration, according to 2010 figures: in Spain, the 3 largest generators' market share, based on the installed capaciry, covers around 59\%. In the Spanish electricity retail market, discarding the last resort supplies, the market shares of the 3 biggest companies add up to $74 \%$ in energy and $90 \%$ in customers (CNE, 2011a).

\subsection{Key trading drivers in OMIP continuous market}

Correlation analysis of the traded volumes in OMIP continuous market during each month serves to identify key trading drivers for such a market. The correlation coefficients of those drivers are shown in Table 3. namely: the OTC volumes, OMIP market makers active at each moment (in December 2011, 4 market makers provided quotations for prompt month, quarter, and year base

\footnotetext{
${ }^{5}$ See e.g. Ofgem (2009).
} 
load futures contracts with the spot price of the Spanish zone as underlying price), the enrolment of financial agents, the enrolment of generation companies belonging to the integrated group of the last resort supplier and the OTC volumes cleared and settled by omiclear.

\subsection{Comparison with the most developed European exchanges}

Despite of the steady development in terms of members and cleared volumes in the lberian power futures market, its figures are still far from the most mature European energy derivatives exchanges (Nasdaq OMX Commodities - traditionally known as Nord Pool, headquartered in Norway and EEX - headquartered in Germany). Table 4 shows the traded volumes and OTC registered volumes, as well as the number of participants in the three exchanges in the year 2011 , compared to the previous year.

Due to OMIP emerging nature, it is the only exchange showing in year 2011 bigger total cleared volumes and members compared to year 2010. The smaller total cleared volumes in EEX in year 2011 are due to the uncertain trading environment, in which traders prefer shorter term maturities (EEX, 2012a). Both the German and Nordic markets present quite larger churn ratios than in the Spanish case (around 8 and 7 respectively, considering OTC and exchange based trading) (Ofgem, 2009). Their exchanges perform quite more efficiently than OMIP, as liquidity exists for all maturities regarding electricity base load products and the other derivatives traded (gas, $\mathrm{CO}_{2}$ and coal (EEX)). In Nasdaq OMX Commodities, some liquidity

Table 2

Evolution of traded volumes in OMIP. CESUR auctions, OTC and demand (TWh). Sources: OMIP-OMIClear (2011), MEFF (2011), CESUR (2011), Intermoney (2012) and REE (2012).

\begin{tabular}{lrlr}
\hline Data in TWh & $\begin{array}{r}\text { Year } \\
2011\end{array}$ & $\begin{array}{l}\text { Year } \\
2010\end{array}$ & \multicolumn{1}{l}{$\begin{array}{l}\text { July 2006-December } \\
2011\end{array}$} \\
\hline OMIP auctions & 1.32 & 0.59 & 57.22 \\
OMIP continuous & 32.87 & 25.19 & 83.79 \\
CESUR auctions & 35.31 & 27.27 & 191.26 \\
Total OTC & 298.20 & 278.84 & 863.47 \\
OTC registered at OMIClear & 27.08 & 29.46 & 89.74 \\
OTC registered at MEFF Power & 3.76 & - & 3.76 \\
Spanish mainland demand at & 255.18 & 260.61 & 1423.44 \\
$\quad$ busbar & & & \\
\hline
\end{tabular}

\section{Table 3}

Correlation coefficients between OMIP continuous traded volumes and the monthly evolution of key trading drivers.

Sources: OMIP-OMIClear (2011) adapted by authors.

\begin{tabular}{ll}
\hline Correlation between OMIP continuous volumes and: & Correlation factor \\
\hline OTC volumes & 0.88 \\
OMIP market makers & 0.82 \\
OMIP financial agents & 0.80 \\
OMIP vertically integrated generation companies & 0.76 \\
OMIClear OTC registered volumes & 0.70 \\
\hline
\end{tabular}

exists for electricity contract for differences hedging the price risk of the Nordic price areas. In EEX, liquidity of peak futures is well developed, and there are also off-peak contracts, though their liquidity is small. Additionally those markets have a much wider range of trading members, with participation of many municipalities and large industrial consumers, balancing the participants' structure and theoretically providing more robust price signals (EEX, 2012b; NASDAQ OMX Commodities, 2012).

\section{Evolution of the hedging efficiency}

\subsection{The measurement of speculation through volume and open interest}

Lucia and Pardo (2008) measure the speculative and hedging activities in futures markets from volume and open interest data. The open interest equals the number of outstanding long positions (or equivalently, short positions) at the end of the day. The open interest increases whenever none of the counterparties involved in a trade is closing out a position and decreases when both parties are closing out a position. It remains the same when only one trader is closing out a position, being this trader replaced by another one. The daily trading volume reflects movements in the speculative activity. The daily open interest captures hedging activities as it excludes all intraday positions taken by day traders, mainly inspired by speculative reasons. Hedgers tend to hold their forward positions longer than speculators.

\subsection{Evolution of the open interest versus cleared volumes in clearing houses}

OMIP-OMIClear and MEFF Power final open interest-i.e. the value published for the last trading session of a given contract - are studied considering the evolution of the cleared volumes per delivery month. Only month contracts of the Spanish zone are analysed. The accumulated cleared volume considers, for each delivery month, the whole cleared volume of the month contract. and the corresponding fractions from the contracts with larger maturity (i.e. the quarter and year contracts containing that month within their delivery periods). In the case of OMIP-OMIClear, base load and peak futures are considered. For MEFF Power, base load swaps are considered, as registration of futures contracts has not happened yet. The division of the final open interest and the accumulated cleared volume is used as a hedging ratio to measure the potential interest of the traders in these contracts for risk management (hedging by means of final open positions and analogous positions established later in the underlying spot market).

Fig. 3 shows the evolution of the final open interest for each month derivative divided by the total cleared volumes of the derivatives with delivery in that month.

Until july 2008 , the hedging ratio of the base load futures contracts fluctuates in a narrow spread $(0.7-1.0)$ as the final open interest is almost equal to the compulsory auction volumes. Afterwards, the

Table 4

Comparison of the Iberian power futures market with the most developed European energy derivatives exchanges.

Sources: OMIP-OMIClear (2011). Nasdaq OMX Commoditics $(2011,2012)$ and EFX (2012b), adapted by authors.

\begin{tabular}{|c|c|c|c|c|c|c|}
\hline & \multicolumn{2}{|c|}{ OMIP-OMIClear } & \multicolumn{2}{|c|}{ Nasdac OMX Commodities } & \multicolumn{2}{|l|}{ EEX } \\
\hline & Year 2011 & Year 2010 & Year 2011 & Year 2010 & Year 2011 & Year 2010 \\
\hline Traded volumes (TWh) & 34.2 & 25.8 & 1028.2 & 1286.7 & 498.6 & 496.4 \\
\hline OTC registered volumes (TWh) & 27.1 & 29.5 & 695.1 & 803.1 & 576.8 & 711.9 \\
\hline Total cleared volumes (TWh) & 61.3 & 55.2 & 1723.3 & 2089.8 & 1075.4 & 1208.3 \\
\hline Number of participants & 38 & 32 & 356 & 361 & 172 & 157 \\
\hline
\end{tabular}




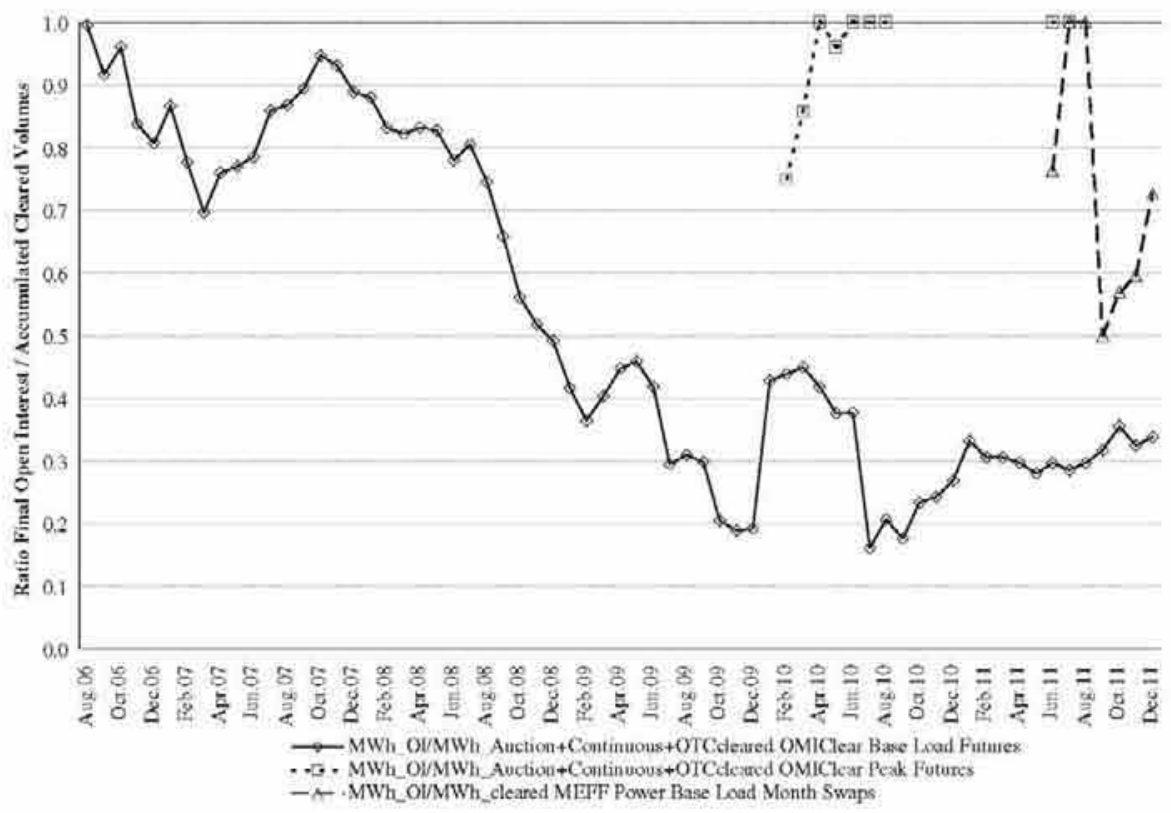

Fig. 3. Evolution of OMIClear and MEFF Power final open interest divided by the total cleared volumes per delivery month for derivatives of the Spanish zone Source: OMIP-OMIClear (2011) and MEFF (2011) adapted by authors.

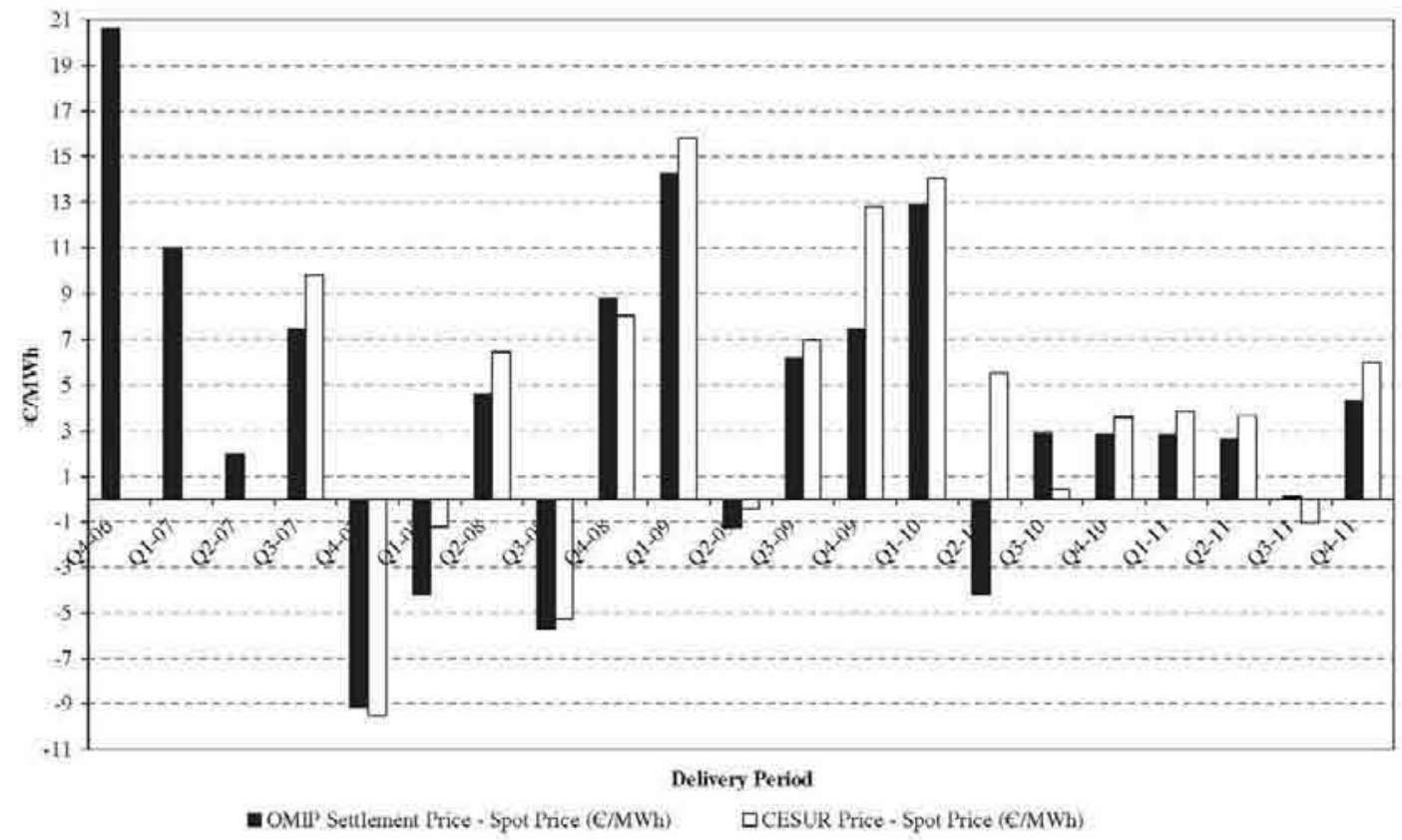

Fig. 4. Evolution of the ex-post forward risk premia in the Iberian energy derivatives exchange and in CESUR auctions. Source: OMIP-OMIClear (2011), CESUR (2011), and OMIE (2011) adapted by authors.

auction volumes become smaller but the continuous volumes and the OTC registered volumes in OMIP-OMIClear grow, as shown in Fig. 2. Therefore the hedging ratio diminishes and oscillates since the beginning of year 2009 in a wider spread $(0.1-0.5)$. In the case of peak futures, the series is composed of few values, as there are only cleared volumes for the months February 2010-August 2010, and June 2011-July 2011. The hedging ratio of the peak futures fluctuates in a narrow spread $(0.7-1.0)$ as almost all the transactions correspond to hedges performed by the Portuguese last resort supplier in auctions for the purchase of regulatorily fixed amounts. Nevertheless, the maximum ratios (1.0) in June 2011 and July 2011 correspond to single OTC registered transactions of those month contracts, due to scarce negotiation of such peak contracts. In the case of base load swaps cleared in MEFF Power, the ratio decreases due to bigger registration of volumes, as shown in Fig. 2 . The series begins in June 2011 , as it is the first month swap with OTC registered volumes. The months of July and August 2011 present the maximum ratio (1.0) due to low negotiation of those contracts.

\section{Evolution of the price efficiency}

The price efficiency is tracked through the ex-post forward risk premium, obtained as the difference of the average forward price during the quotation period of the contract and the resulting average spot price during the delivery period (see e.g. Redl et al., 2009; 
Table 5

Economic impact of the electricity purchased by the Spanish last resort suppliers in CESUR auctions. Source: CESUR (2011) and OMIE (2011) adapted by authors.

\begin{tabular}{|c|c|c|c|c|c|c|c|c|}
\hline Auction & Product & Type & Capacity (MW) & Energy (MWh) & Auction price ( $\epsilon / \mathrm{MWh}$ ) & Spot price ( $\epsilon / M W h$ ) & Premium ( $€ / M W h)$ & Economic impact (E) \\
\hline \multirow[t]{4}{*}{ 9th } & \multirow[t]{2}{*}{ Q3-09 } & base load & 4800 & $10,598,400$ & 42.00 & 35.05 & 6.95 & $73,658,880$ \\
\hline & & peak & 670 & 530,640 & 47.60 & 38.55 & 9.05 & $4,802,292$ \\
\hline & \multirow[t]{2}{*}{ Q4-09 } & base load & 5000 & $11,045,000$ & 45.67 & 32.87 & 12.80 & $141,376,000$ \\
\hline & & peak & 670 & 530,640 & 51.31 & 36.72 & 14.59 & $7,742,038$ \\
\hline \multirow[t]{4}{*}{ 10th } & \multirow{2}{*}{ Q1-10 } & base load & 4800 & $10,363,200$ & 39.43 & 25.38 & 14.05 & $145,602,960$ \\
\hline & & peak & 540 & 414,720 & 43.70 & 29.99 & 13.71 & $5,685,811$ \\
\hline & \multirow[t]{2}{*}{ Q2-10 } & base load & 4800 & 10.483 .200 & 40.49 & 34.97 & 5.52 & $57,867,264$ \\
\hline & & peak & 600 & 468.000 & 44.52 & 39.20 & 5.32 & $2,489,760$ \\
\hline \multirow[t]{2}{*}{11 th } & \multirow[t]{2}{*}{ Q3-10 } & base load & 4000 & $8.832,000$ & 44.50 & 44.07 & 0.43 & $3,797,760$ \\
\hline & & peak & 536 & 424,512 & 50.48 & 49.01 & 1.47 & 624,033 \\
\hline \multirow[t]{2}{*}{12 th } & \multirow[t]{2}{*}{ Q4-10 } & base load & 4000 & $8,836,000$ & 46.94 & 43.33 & 3.61 & $31,897.960$ \\
\hline & & peak & 392 & 310,464 & 53.00 & 48.22 & 4.78 & $1,484,018$ \\
\hline \multirow[t]{2}{*}{ 13th } & \multirow[t]{2}{*}{ Q1-11 } & base load & 4000 & $8,636,000$ & 49.07 & 45.22 & 3.85 & $33,248,600$ \\
\hline & & peak & 306 & 235,008 & 53.99 & 48.66 & 5.33 & $1,252,593$ \\
\hline \multirow[t]{2}{*}{14 th } & \multirow[t]{2}{*}{ Q2-11 } & base load & 4000 & $8,736,000$ & 51.79 & 48.12 & 3.67 & $32,061,120$ \\
\hline & & peak & 406 & 316,680 & 55.13 & 51.25 & 3.88 & $1,228,718$ \\
\hline \multirow[t]{2}{*}{$15 \mathrm{th}$} & \multirow[t]{2}{*}{ Q3-11 } & base load & 3600 & $7,948,800$ & 53.20 & 54.23 & -1.03 & $-8,187,264$ \\
\hline & & peak & 688 & 544,896 & 56.63 & 58.62 & -1.99 & $-1,084,343$ \\
\hline \multirow[t]{2}{*}{16 th } & \multirow[t]{2}{*}{ Q4-11 } & base load & 3800 & $8,394,200$ & 57.99 & 52.01 & 5.98 & $50,197,316$ \\
\hline & & peak & 458 & 357,240 & 63.00 & 58.58 & 4.42 & $1,579,001$ \\
\hline \multicolumn{4}{|c|}{ Total $(\mathrm{MWh} \& \epsilon)$, Weighted Average $(\epsilon / \mathrm{MWh})$} & $98,005,600$ & 46.83 & 40.83 & 5.99 & $587,324,516$ \\
\hline
\end{tabular}

Capitán Herráiz and Rodríguez Monroy, 2009; Furiô and Meneu, 2010; Villaplana and Cartea, 2011). Redl and Bunn (2011) find, through analysis of forward and spot data in the German power market (EEX), that the forward risk premium in electricity is a function of fundamental, behavioural, dynamic, market conduct and shock components. This premium is influenced by the gas prices, the oil price volatility, the generators' market power and the power scarcity. They suggest to use this premium as a market monitoring indicator as higher premium could be caused by market concentration.

\subsection{Comparison of the ex-post forward risk premia in the Iberian} power futures market and the CESUR auctions

Fig. 4 shows the evolution of the ex-post forward risk premium in OMIP and in the CESUR auctions. For OMIP prices, the average settlement price of the prompt quarter base load futures contract in its last month of quotation is employed. The CESUR price corresponds to the equilibrium price of the prompt quarter base load forward contract in the auction celebrated immediately before its delivery.

The price efficiency has improved with the development of the futures market, as the forward risk premia evolve towards smaller values. However, positive values tend to dominate. Capitán Herráiz and Rodriguez Monroy (2010) find that the analysis of OMIP forward risk premia (data from July 2006 to February 2010) shows differences per contract maturity, allowing arbitrage gains through combined trading of month, quarter and year futures contracts. Arbitrage opportunities also arise between OMIP and CESUR due to the differences in their equivalent premia. The large positive premia during 2009 and the first quarter of 2010 are caused by rising forward prices and decreasing spot prices in the lberian energy market. The former were pushed up by uncertainty in global financial markets, tight credit conditions and price increases in energy commodity prices. The latter were decreased by the depressed economic situation and low prices in the power pool with reduced demand and strong penetration of renewables. The smaller spot prices were also influenced by large rainfalls and the effect of gas take-or-pay contracts (Alba Rios and Moreda Díaz, 2010).

The positive forward risk premia in CESUR auctions are usually bigger than in OMIP. The smaller premia during year 2011 are influenced by new regulation-the mechanism solving restrictions for security of supply described in Section 2 affecting the spot price formation and accordingly the forward price levels.

\subsection{Economic impact of CESUR auctions in the energy cost of the last resort supply rates}

Table 5 shows the economic impact on the energy costs of the last resort supply rates - based on CESUR equilibrium prices - due to frequent positive forward risk premium both in base load and peak products. The data span from the 9 th auction (celebrated in June 2009) until the 16th (in September 2011).

The purchase of the Spanish last resort suppliers in CESUR auctions, with delivery until the end of year 2011, has resulted 587 million $€$ more expensive the same amount of electricity valued at the spot price, due to the dominant positive forward risk premium. The only delivery period with negative premium is the third quarter of 2011 , resulting in a saving of 9.3 million $\epsilon$ compared to the spot price valuation.

\section{Energy policy considerations}

The following recommendations are drawn from the facts exposed in Section 2, and the results of the analyses done in Sections 3-5 with the aim of increasing the efficiency of the Iberian power futures market.

\subsection{The need for increased post-trade transparency from the power futures market operator}

OMIP-OMIClear has published quarterly bulletins with basic statistics until the end of 2009 . For the sake of post-trade transparency, its market surveillance department could publish monthly reports analysing key oversight and liquidity indicators. Such market monitoring reports could aggregate statistics of the volumes traded for different groups of trading members (e,g. financial agents, companies belonging to Iberian integrated energy groups -i.e. the traditional "incumbents" - energy companies not belonging to such incumbents, and even market makers) to show which are the most active members. Indication of the number of active companies 
effectively trading would indicate how dynamic this market is. Concentration indexes (e.g. Herfindahl-Hirschman index " $\mathrm{HHI}^{16}$ ) would provide worthy information. Valid references for this kind of monitoring reports are Nasdaq OMX Commodities monthly reports, and EEX market monitoring semiannual reports (NASDAQ OMX Commodities, 2012; EEX, 2011).

OMIP-OMIClear could provide more transparency regarding the net positions of OMIP trading members by including open interest statistics per different traders' categories in the suggested monthly market monitoring report. A good reference is provided by the US Commodity Futures Trading Commission (CFTC), in its disaggregated "Commitments of Traders" (COT) weekly report, showing a breakdown of each Tuesday's open interest for markets in which 20 or more traders hold positions equal or above the reporting levels established by CFTC. The 2 categories of the legacy (i.e. basic) COT reports are very indicative: commercial (hedgers) and non-commercial (speculators). For each category, the COT report shows long and short positions, changes from previous report, percentages of open interest, numbers of traders, and concentration of positions held by the largest four and eight traders (CFTC, 2011). Another worthy structure could be the one provided by the Administrator of CESUR auctions, as it indicates the CESUR matched amounts for 3 separated agents' types: (i) companies owning power plants in Spain; (ii) companies headquartered in Spain; and (iii) integrated business groups owning a last resort supplier (OMEL, 2011).

\subsection{The necessity for trade repositories for a comprehensive oversight by regulators}

The bulk of the Iberian power forward trading is OTC not cleared through a central counterparty. Therefore, the analysis in Section 4 only provides a partial snapshot of the hedging activities of the market participants (e.g. the agents can close their open positions registered in clearing houses through other trades established OTC or through other market mechanisms, e.g. CESUR auctions). In order to have a full picture of the market, enabling the national regulatory authorities to perform a comprehensive oversight, all the energy transactions would have to be reported to such authorities. Current European legislative initiatives, shown in Table 6, are pointing out in that direction.

The Regulation on wholesale energy market integrity and transparency (REMIT) entered in force on December 28, 2011. prohibiting insider trading and market manipulation practices in the European wholesale electricity and natural gas markets (European Union, 2011). The increase in existing transparency levels will produce more competitive and liquid markets, reducing costs to market players and on end-users' supplies (Gensler, 2012). Discussion among all the stakeholders is desired for the proper implementation of these legislative pieces, in order to prevent troublesome overlapping and flaws in this regulatory orchestration, providing more trading confidence to the participants and a sound supervisory framework for the authorities involved. REMIT envisages transaction reporting and inclusion of trading orders. The definition of the reporting mechanism is currently under development by the European Commission. This can take up to 18 months (ACER, 2011b). Such a mechanism should include non-standardised contracts (e.g. reporting could be done every time the price varies according to an indexation formula or once providing the details of such formula) and the orders from the opaque OTC trading to avoid supervisory gaps.

\footnotetext{
"As in CNE (2011b), the "HHI" index is built as the sum of squares of the market shares considering all the market players. Therefore, it ranges between 0 (perfect competition) and 10000 (monopoly). CRE (2012) states that concentration is small with values lower than 1000 and large with values higher than 1800 .
}

The reporting of bilateral contracts e.g. standard contracts as those defined through the European Federation of Energy Traders (EFET) templates-would contribute to price discovery of intragroup transactions. The access to all the OTC data will help to prevent excessive speculation impacting on the prices (Chilton, 2012).

Despite of long lead times for the implementation of the European legislative pieces cited above, national energy regulators can also access to OTC data by own initiative. if stated in their national law. This is the case of the Spanish Energy Commission (CNE). As stated in CNE (2011a), this regulator has access to limited information over OTC power transactions (volumes and transaction prices, through the information voluntarily submitted by the main brokers). On March 5, 2011, the Law of Sustainable Economy was published in the Spanish Official Gazette. The 5th final disposition of this Law modifies the Securities Market Law. enabling the information exchange between CNMV (the Spanish Financial Services Authority empowered to request OTC power data in the Spanish financial market) and the remaining entities composing the MIBEL Regulatory Council ${ }^{7}$. Those entities signed on May 17, 2011, a Multilateral Memorandum of Understanding (MoU) for the efficient coordination in the MIBEL supervision, facilitating the OTC data collection and supervision. On the other hand, the Royal Decree-Law 13/2012, of March 30, transposes the Directives for the internal electricity and gas markets, i.e. Directive 2009/72/EC and Directive 2009/73/EC (MINETUR, 2012b; European Commission, 2009a, 2009b). These two Directives together with other three Regulations constitute the third legislative package for an internal EU gas and electricity market (ACER, 2011a). That Royal Decree-Law modifies the Law of the Electricity Sector (Law 54/1997, of November 27) allowing the Ministry of Industry, the CNE, the Spanish Competition Authority and the European Commission to access during at least 5 years to the data of all the transactions of electricity supply contracts as well as electricity derivatives concluded with wholesale customers and Transmission System Operators (TSOs). Likewise, this Royal Decree-Law modifies the Law of the Hydrocarbons Sector (Law $34 / 1998$, of October 7) allowing the same aforementioned authorities to access during at least 5 years to the data of all the transactions of gas supply contracts as well as gas derivatives concluded with wholesale customers and TSOs, the underground storage system operators, and the Liquefied Natural Gas system operators.

\section{Conclusions}

The traded volumes in the continuous market of the Iberian Energy Derivatives Market - the power futures market managed by OMIP grow steadily since its start on July 3,2006. They are correlated to the OTC volumes, the amount of active market makers in OMIP, the enrolment in OMIP of financial agents and generation companies of vertically integrated groups, and the OTC cleared volumes by OMIP clearing house (OMIClear).

The hedging performance in the Iberian Forward Electricity Market is estimated with aggregated data from the Portuguese and Spanish clearing houses (OMIClear and MEFF Power respectively) through the ratio of the final open interest of a month derivatives contract divided by the accumulated cleared volume for that delivery month. OMIP Spanish base load power futures contracts show the lowest hedging ratios due to good liquidity.

\footnotetext{
"MIBEL. stands for "Mercado Ibérico de Elcctricidad" (Iberian Electricity Market). The MIBEL. Regulatory Council is composed of CNE. CNMV. ERSE (Portuguese National Regulatory Authority) and CMVM (Portuguese Financial Services Authority).
} 


\section{Table 6}

Main European legislative pieces impacting on energy derivatives trading.

Sources: European Union $(2011,2012)$ and European Commission $(2011 a, 2011 b, 2011$ c).

\begin{tabular}{|c|c|c|}
\hline $\begin{array}{l}\text { Legislative } \\
\text { piece }\end{array}$ & $\begin{array}{l}\text { Published } \\
\text { on: }\end{array}$ & Scope \\
\hline REMIT & $\begin{array}{l}\text { Dec. } 8 \\
2011\end{array}$ & $\begin{array}{l}\text { Regulation on wholesale energy market integrity and } \\
\text { transparency }\end{array}$ \\
\hline MiFIR & $\begin{array}{l}\text { Oct. } 20 \text {. } \\
2011\end{array}$ & $\begin{array}{l}\text { Draft regulation on markets in financial instruments and } \\
\text { amending EMIR }\end{array}$ \\
\hline MiFID Il & $\begin{array}{l}\text { Oct. } 20 \text {, } \\
2011\end{array}$ & Draft reviewed directive on markets in financial instruments \\
\hline MAR & $\begin{array}{l}\text { Oct. } 20 \\
2011\end{array}$ & $\begin{array}{l}\text { Draft regulation on insider dealing and market manipulation } \\
\text { (Market Abuse) }\end{array}$ \\
\hline EMIR & $\begin{array}{l}\text { Jul. } 27, \\
2012\end{array}$ & $\begin{array}{l}\text { Regulation on OTC derivatives, central counterparties and } \\
\text { trade repositories }\end{array}$ \\
\hline
\end{tabular}

A larger data set is required to draw robust conclusions for the base load swaps registered in MEFF Power. So far both clearing houses behave complementarily, being OMIClear preferred for larger maturity contracts cleared as futures. As the registration of short maturity contracts is becoming more frequent-daily and weekly contracts-further research could analyse if the hedging ratios of those contracts are bigger, responding to hedging needs close to the delivery period, or smaller as they could be used to close positions from month contracts, either to adjust hedging needs according to physical delivery commitments or to exploit price differences between maturities (arbitrage gains). The hedging ratio has limitations due to a couple of reasons. First, it provides a trading partial snapshot, as the majority of the OTC trading is not centrally cleared and no aggregated data are published. Second, the hedge only exists if the trader does a similar operation in the spot market. Nevertheless, it can be very useful for energy regulators performing market oversight once they access to the details of all the transactions of energy derivatives according to the EU Regulation on Energy Market Integrity and Transparency ("REMIT").

The ex-post forward risk premium, obtained as the difference of the average forward price during the trading period and the underlying spot price during the delivery period, has diminished due to the agents' learning curve and the effect of the fixed price retributing the indigenous coal fired generation. As a result of frequent positive forward risk premia, the electricity purchase by the Spanish last resort suppliers in CESUR auctions, with delivery between July 2009 and December 2011, has resulted 587 million $€$ more expensive than the electricity cost valued at the spot price. Analysis of the economic impact of the contract for differences mechanism defined in Royal Decree 302/2011 is suggested for additional research. This mechanism helps to mitigate the tariff deficit caused by regulated prices for special regime generation.

Further research, based on literature review about regulatory risk, is suggested to quantify the increase in the Iberian forward risk premium due to regulatory risk provoked by intensive introduction of policy measures in Spain and Portugal with urgent nature. Due to time pressure, such measures may lack a robust cost-benefit analysis. The balance between the benefits and cost of imperfect regulation should overcome the costs of the related market failures. The outcomes of the suggested potential research could be very useful for energy regulators streamlining the existing regulation and supervising the performance of the wholesale energy markets.

Finally, despite of the dynamic trading environment, the Iberian Energy Derivatives Market is still much less developed than the European leaders (Nasdaq OMX Commodities and EEX). Its overall efficiency could increase with wider enrolment - there is still much room for international energy companies, financial agents, energy intensive industries and renewable generation companies-, post-trade transparency actions through market operator's monthly oversight reports, and stronger supervision of regulators through integral data access from all trading venues.

\section{References}

Abadie, L.M., Chamorro, J.M., 2009. Income risk of EU coal-fired power plants after Kyoto. Energy Policy 37, 5304-5316.

ACER, 2011a. Questions and answers on the third legislative package for an internal EU gas and electricity market. Agency for the Cooperation of Energy Regulators. 3 March 2011, Ljubljana. Available from: <www.acer.europa.eu/ portal/page/portal/ACER_HOME/Communication/News >.

ACER, 2011b. Questions and answers on REMIT. Agency for the Cooperation of Energy Regulators. Ljubljana. Available from: <www.acer.europa.eu/portal page/portal/ACER_HOME/Activities/REMIT/

ACER\%20Guidance $\% 20$ and $\% 20$ Questions\% $20 \% 20$ Answers $\% 20$ on $\% 20$ REMIT/ QuestionsAndAnswers3\%20ap final\%20vzu_cca.pdf > (last updated 20.12.11).

Alba Ríos, J.J., Moreda Díaz, E., 2010. Competencia en el mercado mayorista de electricidad. In: Pons, Marcial (Ed.), Anuario de la competencia. Fundación ICO-UAB, Madrid 2009, pp. 215-293.

BME, 2011. MEFF Power comenzará a funcionar el 21 de marzo. MEFF press release, on March 2, 2011. Bolsas y Mercados Españoles (BME), Madrid. Available from: $\langle$ www.bolsasymercados.es/aspx/RevOnLine/NPrensa_BME.aspx?id=17903〉.

Cabeza, L., 2011. Llegan los contadores inteligentes. Entrelíneas. Revista digital de Red Eléctrica de España, 20. abril-junio, 2011. Available from: <www. revistaentrelineas.es/20/entretemas/reportajes/ llegan-los-contadores-inteligentes?page=full $\rangle$.

Cabral, L.M. 2012. Faturas de luz e gás. Governo garante que haverá reducão de custos. Diário de Notícias. 8 August 2012. Available from: <www.dn.pt/inicio/ economia/interior.aspx?content_id $=2710269$ \&page $=-1\rangle$.

Capitán Herráiz, A., Rodríguez Monroy, C., 2009. Analysis of the efficiency of the Iberian power futures market. Energy Policy 37, 3566-3579.

Capitán Herráiz, A., Rodríguez Monroy, C., 2010. Analysis of the price efficiency in the lberian power forward contracting mechanisms. In: Proceedings of the 7 th International Conference on the European Energy Market. June 23-25, 2010 Madrid.

CESUR, 2011. Oficial websites of Spanish Bilateral Contracting Auctions for last resort supplies (CESUR auctions): 1 st to 5 th auctions. Available from: < www. subasta-cesur.eu/auction.asp >; from 6 th onwards 〈www.subastascesur.omel. es/frames/index.jsp >

CFTC, 2011. Disaggregated commitments of traders report, explanatory notes. U.S Commodity Futures Trading Commission (CFTC). Available from: <www.cftc. gov/MarketReports/CommitmentsofTraders/DisaggregatedExplanatoryNotes/ index.htm>.

Chilton, B., 2012. Speculators and commodity prices-Redux. Speeches \& Testimony, Commissioner Bart Chilton. February 24, 2012. Commodity Futures Trading Commssion (CTFC). Washington. Available from: <www.cftc.gov/ PressRoom/SpeechesTestimony/chiltonstatement022412>.

CNE, 2011a. Spanish energy regulator's annual report to the European Commission. 22 July 2011. Comisión Nacional de Energía (CNE), Madrid. Available from: (www.energy-regulators.eu/portal/page/portal/EER_HOME/EER_PUBLl CATIONS/NATIONAL REPORTS/National\%20Reporting\%202011/NR En/ C11_NR Spain-EN.pdf $>$.

CNE, 2011b. Informe sobre la evolución de la competencia en los mercados de gas y electricidad. Periodo 2007-2009, September 1, 2011. Comisión Nacional de Energía (CNE), Madrid. Available from: <www.cne.es/cne/doc/publicaciones/ PA-competencia-011.pdf $>$. 
CNE, 2012a. Informe anual de supervisión del mercado eléctrico, año 2011. Comisión Nacional de Energía, 2 de febrero de 2012. Madrid. Available at: 〈www.cne.es/cne/doc/publicaciones/PA_SUP-mercado-electrico11.pdf〉.

CNE, 2012b. Informe sobre el sector energético español. Comisión Nacional de Energía. 7 de marzo de 2012, Madrid. Available from: 〈www.cne.es/cne/ Publicaciones accion $=3 \&$ id $=3026$ \&id nodo $=32>$.

Conchado, A., Linares, P., 2010. Estimación de los beneficios de la gestión activa de la demanda. Revisión del estado del arte y propuestas, Cuadernos Económicos de ICE 79, 187-212.

CRE, 2011. Le fonctionnement des marchés de gros de l'électricité. du $\mathrm{CO}_{2}$ et du gaz natural. Rapport 2010-2011, Novembre 2011. Commission de Régulation de L'Énergie, Paris. Available from: (www.cre.fr/documents/publications/ rapports-thematiques/rapport-de-surveillance-des-marches-2010-2011 >

CRE, 2012. Observatoire des marchés de l'électricité et du gaz. 4 trimestre 2011 , March 2, 2012. Commission de Régulation de L'Énergie, Paris. Available from: 〈www.cre.fr/marches/observatoire-et-indicateurs-des-marches\#section1〉.

EEX, 2011. Market Monitor by the Market Surveillance of EEX, Q1 \& Q2/2011. European Energy Exchange AG, Leipzig. Available from: <http://cdn.eex.com/ document/100052/20111028_EEX\%20MARKET\%20MONITOR\%20HJ\%201\%202011\%20eng\%201.2.pdf

EEX, 2012a. Press release: EEX Review of 2011-EEX asserts itself in a difficult market environment-boom in short-term trading-Natural Gas Marke reaches record level. 12 January 2012. European Energy Exchange AG, Leipzig. Available from: <http://cdn.eex.com/document/103018/20120112_EEX_Jah reszahlen_2011.pdf $\rangle$

EEX, 2012b. EEX Company and Products, as of February 2012. European Energy Exchange AG, Leipzig. Available from: <http://cdn.eex.com/document/ 103364/EEX_Company_Products_E.pdf $>$.

Energy Market Price, 2012. Spain halts the award of new feed-in tariff contracts 23 March 2012. Available from: <www.energymarketprice.com/SitePage. asp? Command=ArticleView $\& \mathrm{ID}=8342\rangle$

European Commission, 2009a. Directive 2009/72/EC of the European Parliament and of the Council of 13 July 2009 concerning common rules for the internal market in electricity and repealing Directive 2003/54/EC. Available from: $\langle$ http://eur-lex.europa.eu/LexUriServ/LexUriServ. do? uri=OJ:L:2009:211:0055:0093:EN:PDF

European Commission, 2009b. Directive 2009/73/EC of the European Parliamen and of the Council of 13 July 2009 concerning common rules for the interna market in natural gas and repealing Directive 2003/55/EC. Available from $\langle$ http://eur-lex.europa.eu/LexUriServ/LexUriServ. do?uri=OJ:L:2009:211:0094:0136:en:PDF >

European Commission, 2011a. Proposal for a regulation of the European Parliament and of the Council on markets in financial instruments and amending regulation [EMIR] on OTC derivatives, central counterparties and trade repositories. Brussels, 20 October 2011. COM(2011) 652 final. 2011/0296 (COD). Available from: 〈http://ec.europa.eu/internal_market/securities/docs/ isd/mifid/COM_2011_652_en.pdf $\rangle$.

European Commission, 2011b. Proposal for a Directive of the European Parliament and of the Council on markets in financial instruments repealing Directive 2004/39/EC of the European Parliament and of the Council, Brussels. 20 October 2011. COM(2011) 656 final, 2011/0298 (COD). Available from: $\langle\mathrm{http}: /$ ec.europa.eu/internal_market/securities/docs/isd/mifid COM_2011_656_en.pdf >

European Commission, 2011c. Proposal for a regulation of the European Parliament and of the Council on insider dealing and market manipulation (marke abuse), Brussels, 20 October 2011. COM (2011) 651 final, 2011/0295 (COD). Available from: <http:/ec.europa.eu/internal_market/securities/docs/abuse/ COM 2011651 en.pdf $\rangle$.

European Union, 2011. Regulation (EU) no. 1227/2011 of the European Parliament and of the Council of 25 October 2011 on wholesale energy market integrity and transparency. Official Journal of the European Union. December 8, 2011 Available from: <http://eur-lex.europa.eu/LexUriServ/LexUriServ. do? uri=OJ:L:2011:326:0001:0016:EN:PDF >

European Union, 2012. Regulation (EU) no 648/2012 of the European Parliament and of the Council of 4 July 2012 on OTC derivatives, central counterparties and trade repositories. Official Journal of the European Union. July 27, 2012 Available from: 〈http://eur-lex.europa.eu/LexUriServ/LexUriServ. do?uri=OJ:L:2012:201:0001:0059:EN:PDF $\rangle$

Fabra, N. 2009. Mesa Redonda: Temas Avanzados en Economía Energética. IV Congreso de la Asociación Española para la Economía Energética. IPTS, Seville, January 2009. Available from: <www.eco.uc3m.es/nfabra/Docencia/Energy/ Sevilla.pdf $>$.

Furió, D., Meneu, V., 2010. Expectations and forward risk premium in the Spanish deregulated power market. Energy Policy 38, 784-793.

García Breva, J., 2012. Renovables sin complejos. Energías Renovables, 30 March 2012. Available from: <www.energias-renovables.com/energias/renovables/ index/pag/perfil/colleft//colright/perfil/tip/articulo/pagant/perfil/pagid/19840/ botid/33/>

Gelabert, L, Labandeira, X, Linares, P., 2011. An ex-post analysis of the effect of renewables and cogeneration on Spanish electricity prices. Energy Economics $33,59-65$

Gensler, G., 2012. Remarks on the Dodd-Frank Act at the 6th Annual Capital Markets Summit Hosted by the U.S. Chamber of Commerce. "Transparent Markets-Key to a Growing Economy", Speeches \& Testimony. Chairman Gary Gensler, March 28, 2012. Commodity Futures Trading Commssion (CTFC)
Washington. Available from: 〈http://www.cftc.gov/PressRoom/SpeechesTesti mony/opagensler-110>.

Honoré, A., 2011. The Spanish Gas Market: Demand Trends Post Recession and Consequences for the Industry. NG 55, July 2011. The Oxford Institute for Energy Studies. Available from: 〈www.oxfordenergy.org/wpcms/wp-content/ uploads/2011/08/NG 55.pdf >

Intermoney, 2012. El Mercado Eléctrico en España, diciembre 2011, Madrid. 13 de enero de 2012. im energía sa, consultoría. p. 57

Joskow, P.L., Wolfram, C.D., 2011. Dynamic pricing of electricity. Working paper. MIT Economics, Massachussets. Available from: <http://economics.mit.edu/ files/7428>

Linares, P., Conchado, A., 2010. The Economics of new nuclear power plants in liberalized electricity markets. WP 04/2010. Economics for Energy. Available from: 〈www.eforenergy.org/docpublicaciones/documentos-de-trabajo/ WP04-2010.pdf >

Lucia, J., Pardo, A., 2008. On measuring speculative and hedging activities in futures markets from volume and open interest data. Applied Economics, 1-9.

MEFF, 2011. Energy Derivatives, Historic Data, Detail. MEFF Power daily data between March 21, 2011-December 31, 2011. Available from: 〈http://www. meff.es/aspx/DerEnergia/HistoricoDetalle.aspx?id=ing >

MINETUR-Ministerio de Industria, Energía y Turismo, 2012a. Real Decreto-ley $1 / 2012$, de 27 de enero, por el que se procede a la suspensión de los procedimientos de preasignación de retribución y a la supresión de los incentivos económicos para nuevas instalaciones de producción de energía elêctrica a partir de cogeneraciôn, fuentes de energía renovables y residuos. Spain's Official Journal. BOE Number 24, January 28, 2012. Available from: 〈www.boe.es/boe/dias/2012/01/28/pdfs/BOE-A-2012-1310.pdf〉

MINETUR-Ministerio de Industria, Energía y Turismo, 2012b. Real Decreto-Ley 13/ 2012, de 30 de marzo, por el que se transponen directivas en materia de mercados interiores de electricidad y gas y en materia de comunicaciones electrónicas, y por el que se adoptan medidas para la corrección de las desviaciones por desajustes entre los costes e ingresos de los sectores eléctrico y gasista. Spain's Official Journal, BOE Number 78, March 31, 2012. Available from: 〈www.boe.es/boe/dias/2012/03/31/pdfs/BOE-A-2012-4442.pdf〉.

MINETUR-Ministerio de Industria, Energía y Turismo, 2012c. El Gobierno reduce los costes del sistema eléctrico y limita la subida de la luz al $7 \%$ en abril. Press release. March 30, 2012. Available from: <www.minetur.gob.es/es-es/gabine teprensa/notasprensa/documents/npmediasenergia300312.pdf $\rangle$.

MITyC-Ministerio de Industria, Turismo y Comercio, 2009a. Real Decreto 485/ 2009 , de 3 de abril, por el que se regula la puesta en marcha del suministro de último recurso en el sector de la energía eléctrica. Spain's Official Journal, BOE Number 82, April 4, 2009. Available from: <www.boe.es/boe/dias/2009/04/04/ pdfs/BOE-A-2009-5618.pdf >

MITyC-Ministerio de Industria, Turismo y Comercio, 2009b. El Plan Contador ayudará a los consumidores a ahorrar electricidad y abaratar su factura. press release. June 8, 2009. Available from: <www.minetur.gob.es/es-es/gabinete prensa/notasprensa/documents np\%20envío\%20cne\%20plan\%20contador\%2008\%2006\%2009.pdf

MITyC-Ministerio de Industria, Turismo y Comercio, 2010. Real Decreto 134/2010, de 12 de febrero, por el que se establece el procedimiento de resolución de restricciones por garantía de suministro y se modifica el Real Decreto 2019/ 1997 , de 26 de diciembre, por el que se organiza y regula el mercado de producción de energía eléctrica. Spain's official Journal, BOE, Number 51, February 27, 2010 Available from: <www.boe.es/boe/dias/2010/02/27/pdfs/ BOE-A-2010-3158.pdf $>$

MITyC-Ministerio de Industria, Turismo y Comercio, 2011a. Resolución de 8 de febrero de 2011, de la Secretaría de Estado de Energía, por la que se fijan las cantidades de carbón, el volumen máximo de producción y los precios de retribución de la energía, para el año 2011 a aplicar en el proceso de resolución de restricciones por garantía de suministro. Spain's Official Journal, BOE, Number 35, February 10, 2011. Available from: 〈www.boe.es/boe/dias/ 2011/02/10/pdfs/BOE-A-2011-2542.pdf >

MITyC-Ministerio de Industria, Turismo y Comercio, 2011b. Real Decreto 302/ 2011 , de 4 de marzo, por el que se regula la venta de productos a liquidar por diferencia de precios por determinadas instalaciones de régimen especial y la adquisición por los comercializadores de último recurso del sector eléctrico. Spain's Official Journal, BOE Number 55, March 5, 2011. Available from: 〈www.boe.es/boe/dias/2011/03/05/pdfs/BOE-A-2011-4119.pdf〉.

Moreno, F., 2011. Characterization of peaks and valleys of electricity demand. Application to the spanish mainland system in the period 2000-2020. Energy and Power Engineering 2011 (3), 537-546.

Moreno, F., Martínez-Val, J.M., 2011. Collateral effects of renewable energies deployment in Spain: impact on thermal power plants performance and management. Energy Policy 39, 6561-6574.

NASDAQ OMX Commodities, 2011. Market Report, December 2010. Nasdaq OMX Commodities and Nord Pool Spot, Lysaker. Available from: 〈www.nasdaqomx commodities.com/digitalAssets/72/72641_2010dec.pdf $>$.

NASDAQ OMX Commodities, 2012. Market Report, December 2011. Nasdaq OMX Commodities and Nord Pool Spot, Lysaker. Available from: 〈www.nasdaqomx commodities.com/digitalAssets/77/77547_2011dec.pdf

OFGEM, 2009. Liquidity in the GB wholesale energy markets. Discussion Paper. Ref. 62/09, 08 June 2009. Office for Electricity and Gas Markets (OFGEM), London. Available from: <www.ofgem.gov.uk/Markets/WhlMkts/CompandEff/ Documents 1/Liquidi ty\%20in\%20the\%20GB\%20wholesale\%20energy\%20markets.pdf > 
OMEL, 2011. Resultados de la XVI subasta TUR electricidad, cuarto trimestre 2011. OMEL Mercados Agencia de Valores, S.A.U. Available from: <www.subastasce sur.omel.es/files/resultados_de_la_subasta_tur_electricidad_cuarto_trimes tre_2011_2.pdf $>$.

OMIE, 2011. Resultados del mercado. OMl-POLO ESPAÑOL, S.A, (Iberian Marke Operator, Spanish Pool). Available from: <www.omie.es/files/flash/Resultados Mercado.swf $>$.

OMIP, 2011. OMIP 2010 Results Show Strong Growth. Press release. 5 January 2011. Available from: <http://omip.pt/Press/PressReleasestodos/tabid/100/ nid/1183/language/en-GB/Default.aspx $\rangle$.

OMIP-OMIClear, 2011. OMIP-OMIClear Daily Market Bulletins of the MIBEL Derivatives Market. July 3, 2006-December 31, 2011. Available from: 〈www.omip.pt/Downloads/tabid/104/language/en-GB/Default.aspx 〉.

Ordóñez, L., 2012. El gran reto energético es fijar un marco regulatorio serio donde cada tecnología sea rentable por sî misma. La nueva España, 22 March 2012. Available from: 〈www.Ine.es/asturama/2012/03/21/gran-reto-energetico-con siste-fijar-marco-regulatorio-serio-tecnologia-sea-rentable/1217467.html $\rangle$.
Redl, C., Haas, R., Huber, C., Böhm, B., 2009. Price formation in electricity forward markets and the relevance of systematic forecast errors. Energy Economics 31 356-364

Red1, C., Bunn, D., 2011. Determinants of the Premium in Forward Contracts. Working paper, version March 2011. Vienna University of Technology \& London Business School. Available from: <www.eeg.tuwien.ac.at/eeg.tuwien. ac.at_pages/publications/pdf/RED_PAP_2011_1.pdf $\rangle$.

REE-Red Elêctrica de España, S.A., REE (Spanish Electricity System Operator), 2012 Informes mensuales, Red Eléctrica de España (REE), Madrid. Available from: 〈www.ree.es/sistema_electrico/boletin_mensual_ree.asp 〉.

Sensfuß, F., Ragwitz, M., Genoese, M., 2008. The merit-order effect: a detailed analysis of the price effect of renewable electricity generation on spot market prices in Germany. Energy Policy 36, 3076-3084.

Villaplana, P., Cartea, A., 2011. Un análisis de la evolución de los precios a plazo de energía eléctrica en España. Los nuevos mercados energéticos: 193-242. Fundación de Estudios Financieros, Colección Papeles de la Fundación no 41, Madrid. 